\title{
Investigation of efficient synthesis of 1,8-dioxo-octahydroxanthene derivatives under solvent-free grinding method
}

\author{
R. Borah*, P. Dutta and P. Sarma
}

Department of Chemical Sciences, Tezpur University, Napaam-784028, Tezpur-Assam, India

C H R O N I C L E

Article history:

Received March 27, 2013

Received in Revised form

July 27, 2013

Accepted 22 August 2013

Available online

24 August 2013

Keywords:

PANI (Polyaniline)

Ferric nitrate nonahydrate

Solvent-free

1,8-Dioxo-octahydroxanthenes

Mechanochemical energy

Reusable catalyst \begin{abstract}
A B S T R A C T
In these studies, we had observed polyaniline (PANI) supported $p$-toluene sulfonic acid (TsOH) and $\mathrm{FeCl}_{3}\left(\mathrm{PANI}-\mathrm{TsOH}, \mathrm{PANI}-\mathrm{FeCl}_{3}\right)$ as excellent reusable solid acid catalysts for the synthesis of 1, 8-dioxo-octahydroxanthene derivatives $\mathbf{4}(\mathbf{a}-\mathbf{g})$ under solvent-free grinding method at mild conditions. Additionally, in the same optimized condition ferric nitrate nonahydrate also acted as (non-reusable) very reactive inexpensive Lewis acid catalyst. The ferric nitrate nonahydrate lost its activity in the form of Clayfen (Clay-supported ferric nitrate) catalyst.
\end{abstract}

\section{Introduction}

The combined application of solvent-free mechanochemical process ${ }^{1}$ and reusable solid acid catalyst in organic synthesis will reduce pollution and cost, simplify the work-up steps, and eliminate excessive and wasteful heating. The flexibility in choice of all types of reagent pairs at room temperature is an important aspect of mechanochemical processes. The potential use of reusable supported solid acid catalysts ${ }^{2,3}$ in organic synthesis make reaction methods more convenient, economic and environmentally benign, since the product purification is simple due to easy separation of insoluble support from the reaction medium ${ }^{4,5}$.

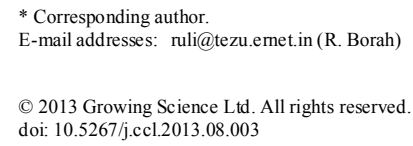


The syntheses of xanthene derivatives are important in medicinal chemistry as antibacterials, antioxidant, antifungal, antiviral and anti-inflammatory agents ${ }^{6}$, photodynamic therapy and antagonists for the paralyzing action of zoxazolamine. ${ }^{7}$ In material science, they are applied as leuco $\mathrm{dye}^{8}$ in laser technologies, and as $\mathrm{pH}$ sensitive fluorescence materials for visualization of biomolecules. ${ }^{9}$ Some xanthene derivatives are presented in natural products with different biological activities, e.g. strong and selective inhibition of MAO-A, antitumor activity. ${ }^{10,11}$ For 1,8-dioxooctahydroxanthene derivatives, the inherent reactivity of pyran ring ${ }^{12}$ makes them building block of several natural products. In literature, a number of synthetic approaches ${ }^{13,14}$ have been developed for the preparation of 1,8-dioxo-octahydroxanthenes involving acid or base catalyzed condensation of aldehydes and 5, 5-dimethyl-1,3-cyclohexanedione (Scheme 1) in solvent-free condition, ionic liquid and aqueous medium. Each of these methods have their own merits but also suffers from one or more drawbacks such as longer reaction time, high temperature, tedious work-up processes, low yield and non-recycling of catalysts. Therefore, the synthesis of 1, 8-dioxo-octahydroxanthene derivatives require the investigation of novel routes with efficient recyclable catalyst at mild condition, short reaction time and simple work-up procedure for isolation of product.

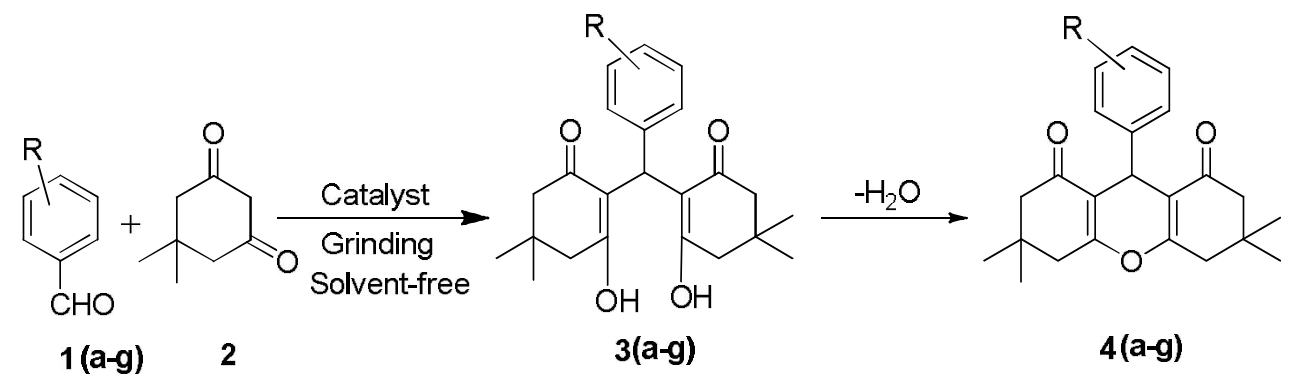

Where $\mathrm{R}=\mathrm{H}(1 \mathrm{a}), 4-\mathrm{Cl}(1 \mathrm{~b}), 4-\mathrm{NO}_{2}(1 \mathrm{c}), 3-\mathrm{NO}_{2}(1 \mathrm{~d}), 4-\mathrm{OH}(1 \mathrm{e}), 4-\mathrm{OMe}(1 \mathrm{f}), 2-\mathrm{Cl}(1 \mathrm{~g})$

Scheme 1: Synthesis of xanthenedione derivatives

In this view point, we were interested to study the activities of $p$-toluene sulfonic acid (TsOH), $\mathrm{FeCl}_{3}$ and ferric nitrate nonahydrate as reusable supported solid acid catalysts (PANI-TsOH, PANI$\mathrm{FeCl}_{3}$, Clayfen) for the synthesis of 1,8-dioxo-octahydroxanthene derivatives from aromatic aldehydes and 5,5-dimethyl-1,3-cyclohexanedione (Scheme 1) in mild conditions using polyaniline and K-10 Montmorillonite as inert supports.

\section{Results and Discussion}

In continuation ${ }^{15-17}$ of our development of environmentally benign syntheses, we examined the catalytic activity of supported acids (PANI-TsOH, PANI-FeCl ${ }_{3}$, Clayfen) and conventional Brønsted or Lewis acid $\left(\mathrm{TsOH}, \mathrm{FeCl}_{3}, \mathrm{Fe}\left(\mathrm{NO}_{3}\right)_{3} .9 \mathrm{H}_{2} \mathrm{O}\right)$ catalysts in the synthesis of xanthenedione derivatives from aromatic aldehydes and 5,5-dimethyl-1,3- cyclohexanedione in solution under reflux and solventfree grinding condition at ambient temperature. In this context, to study the activity of various catalysts in solution and solvent-free grinding conditions we selected the reactions of $p$ chlorobenzaldehyde $(1 \mathrm{mmol})$ and 5,5-dimethyl-1,3-cyclohexanedione $(2 \mathrm{mmol})$ which led to xanthenedione derivative 4 . The results are shown in Table 1.

Table 1. Optimization of conditions of the reaction of 4-chlorobenzaldehyde and 5, 5-dimethyl 1, 3cyclohexanedione in chloroform under reflux and solvent-free grinding.

\begin{tabular}{|c|c|c|c|c|c|c|c|}
\hline \multirow{2}{*}{ Entry } & \multirow{2}{*}{ Catalysts } & \multirow{2}{*}{$\begin{array}{l}\text { Amount } \\
(\mathrm{mmol})\end{array}$} & \multirow{2}{*}{$\begin{array}{l}\text { Time } \\
(\mathrm{min})\end{array}$} & \multirow{2}{*}{ Method $^{\text {a }}$} & \multicolumn{2}{|c|}{ Product yields $(\%)$} & \multirow{2}{*}{$\begin{array}{c}\text { Total conversion } \\
(\%)\end{array}$} \\
\hline & & & & & Diol 3b & Dione $\mathbf{4 b}$ & \\
\hline 1 & $\mathrm{TsOH} / \mathrm{FeCl}_{3} / \mathrm{Fe}\left(\mathrm{NO}_{3}\right)_{2} .9 \mathrm{H}_{2} \mathrm{O}$ & 0.1 & $3 \mathrm{~h} / 3 \mathrm{~h} / 30$ & A & $20 / 25 / 58$ & $-/-/ 42$ & $20 / 25 / 100$ \\
\hline 2 & PANI-TsOH/PANI-FeCl $/$ /Clayfen & 0.1 & $45 / 45 / 20$ & A & $54 / 60 / 65$ & $46 / 40 / 35$ & $100 / 100 / 100$ \\
\hline 3 & $\mathrm{TsOH} / \mathrm{FeCl}_{3} / \mathrm{Fe}\left(\mathrm{NO}_{3}\right)_{2} \cdot 9 \mathrm{H}_{2} \mathrm{O}$ & 0.1 & $55 / 20 / 10$ & $\mathrm{~B}$ & $30 / 28 / 10$ & $70 / 72 / 90$ & $100 / 100 / 100$ \\
\hline 4 & PANI-TsOH $/ \mathrm{PANI}-\mathrm{FeCl}_{3} /$ Clayfen & 0.1 & $25 / 15 / 60$ & B & $15 / 10 / 43$ & $85 / 90 / 57$ & $100 / 100 / 100$ \\
\hline 5 & $\mathrm{TsOH} / \mathrm{FeCl} l_{3} / \mathrm{Fe}\left(\mathrm{NO}_{3}\right)_{2} .9 \mathrm{H}_{2} \mathrm{O}$ & 0.05 & $90 / 70 / 15$ & B & $10 / 10 / 5$ & $45 / 53 / 70$ & $55 / 63 / 75$ \\
\hline 6 & $\mathrm{Fe}\left(\mathrm{NO}_{3}\right)_{2} .9 \mathrm{H}_{2} \mathrm{O}$ & 0.2 & 10 & B & 8 & 92 & 100 \\
\hline 7 & 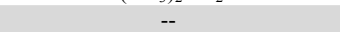 & -- & 40 & B & $90^{14}$ & -- & 90 \\
\hline
\end{tabular}

${ }^{a,}$ Method A : Using $3 \mathrm{ml}$ of chloroform under reflux condition; Method B : Solvent-free grinding method. 
We have observed that with all catalysts (Table 1, Entries 3-4) the product selectivity for $\mathbf{4 b}$ in solvent-free grinding method increases as compared to reactions (Entries 1,2) in chloroform. The above reaction was also observed in other polar (ethanol, acetone, THF) and non-polar solvents (dichloromethane, toluene) in presence of $0.1 \mathrm{mmol}$ of catalysts. We observed less reactive or non selective nature of the supported/traditional form of $\mathrm{TsOH}, \mathrm{FeCl}_{3}$ and ferric nitrate nonahydrate in solution. The catalysts $\mathrm{TsOH}$ and $\mathrm{FeCl}_{3}$ transformed into more reactive and selective catalysts on PANI support (Table 1, entries 4) under solvent-free medium for the formation of product $\mathbf{4 b}$ as compared to Clayfen(Clay-supported ferric nitrate) catalyst. It was observed that ferric nitrate nonahydrate lost its activity and selectivity in the form of Clayfen catalyst. The optimized condition utilized $0.1 \mathrm{mmol}$ of polyaniline supported acids $\left(\mathrm{TsOH}, \mathrm{FeCl}_{3}\right)$ and $\mathrm{Fe}\left(\mathrm{NO}_{3}\right)_{3} \cdot 9 \mathrm{H}_{2} \mathrm{O}$ catalysts in solvent-free grinding method (entries 3-4). We observed incompletion of the reactions with 0.05 mmol of unsupported $\mathrm{TsOH}, \mathrm{FeCl}_{3}$ and $\mathrm{Fe}\left(\mathrm{NO}_{3}\right)_{3} \cdot 9 \mathrm{H}_{2} \mathrm{O}$ catalysts (Table 1, Entry 5).

To see the feasibility of the reaction in solvent-free method we had extended the above standard condition with other aromatic aldehydes containing both electron withdrawing and donating groups using supported acid (PANI-TsOH, PANI-FeCl ${ }_{3}$ ) and unsupported acid (TsOH, $\mathrm{FeCl}_{3}$, $\left.\mathrm{Fe}\left(\mathrm{NO}_{3}\right)_{3} \cdot 9 \mathrm{H}_{2} \mathrm{O}\right)$ catalysts. All these results are summarized in Table 2.

Table 2. Substituent effect of aromatic aldehydes for the synthesis of 1,8-dioxo-octahydroxanthene derivatives 4 in solvent-free grinding method.

\begin{tabular}{|c|c|c|c|c|c|}
\hline \multirow{2}{*}{ Entry } & \multirow{2}{*}{ Catalysts $^{\mathrm{a}}$} & \multirow{2}{*}{ Substrate } & \multirow{2}{*}{ Time (min) } & \multicolumn{2}{|c|}{ Product vields $(\%)^{\mathrm{b}} \mathrm{Mp}(\text { reported })^{19,14,18 \mathrm{~b}}$} \\
\hline & & & & Diol 3(a-g) & Dione 4(a-g) \\
\hline 1 & $\mathrm{C} / \mathrm{D} / \mathrm{E} / \mathrm{F} / \mathrm{G}$ & $\mathrm{C}_{6} \mathrm{H}_{5-}$ & $45 / 25 / 25 / 15 / 10$ & $55 / 20 / 52 / 17 / 15: 195(193-195)$ & $45 / 80 / 48 / 83 / 85: 204(205)$ \\
\hline 2 & $\mathrm{C} / \mathrm{D} / \mathrm{E} / \mathrm{F} . / \mathrm{G} / \mathrm{H}$ & $4-\mathrm{ClC}_{6} \mathrm{H}_{4}$ & $55 / 20 / 20 / 15 / 10 / 60$ & $30 / 15 / 28 / 16 / 10 / 43 ; 141(140-142)$ & $70 / 85 / 72 / 84 / 90 / 57 ; 231(228-230)$ \\
\hline 3 & $\mathrm{C} / \mathrm{D} / \mathrm{E} / \mathrm{F} / \mathrm{G}$ & $4-\mathrm{NO}_{2} \mathrm{C}_{6} \mathrm{H}_{4}$ & $40 / 30 / 60 / 30 / 12$ & 47/8/32/13/14; $187(188-190)$ & $53 / 92 / 68 / 87 / 86 ; 219(216-218)$ \\
\hline 4 & $\mathrm{C} / \mathrm{D} / \mathrm{E} / \mathrm{F} / \mathrm{G}$ & $3-\mathrm{NO}_{2} \mathrm{C}_{6} \mathrm{H}_{4}$ & $60 / 25 / 30 / 15 / 10$ & 27/12/46/9/11; 196 (198-199) & 73/88/54/91/89; 171 (170-173) \\
\hline 5 & $\mathrm{C} / \mathrm{D} / \mathrm{E} / \mathrm{F} / \mathrm{G}$ & $4-\mathrm{OHC}_{6} \mathrm{H}_{4}$ & $45 / 60 / 60 / 55 / 60$ & $25 / 12 / 17 / 9 / 18 ; 191(190-192)$ & $75 / 89 / 83 / 91 / 82 ; 250(249-251)$ \\
\hline 6 & $\mathrm{C} / \mathrm{D} / \mathrm{E} / \mathrm{F} / \mathrm{G}$ & $4-\mathrm{OMeC}_{6} \mathrm{H}_{4}$ & $10 / 10 / 15 / 10 / 10$ & ------ & 94/96/95/97/98; 243 (241-243) \\
\hline 7 & $\mathrm{C} / \mathrm{D} / \mathrm{E} / \mathrm{F} / \mathrm{G}$ & $2-\mathrm{ClC}_{6} \mathrm{H}_{4}$ & $20 / 15 / 20 / 10 / 15$ & $46 / 16 / 7 /-/-; 203(203-204)$ & $54 / 84 / 93 / 97 / 95 ; 229(229-230)$ \\
\hline
\end{tabular}

The results in Table 2 indicated that the PANI supported TsOH and $\mathrm{FeCl}_{3}$ catalysts are superior regarding the time of reaction and product selectivity with all aromatic aldehydes (Table 2) as compared to unsupported catalysts. The activity of the PANI supported acid catalyst depends on the strength of non-bonding interaction between the -NH group of support and acid catalyst by the donation of lone pair of electron on the nitrogen atom. The strong interaction of ferric ion with the Montmorillonite clay decreases the reactivity of ferric nitrate nonahydrate in the supported form (Entry 2). The three supported catalysts were found to be inactive with pentanal. Furaldehyde forms polymeric product with these catalysts.

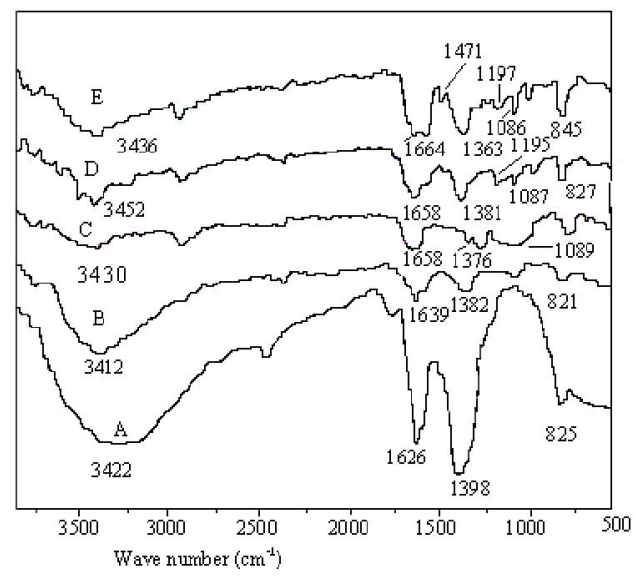

Fig. 1 FT-IR monitoring on the progress of reaction .A: Spectra of $\mathrm{Fe}\left(\mathrm{NO}_{3}\right)_{3} .9 \mathrm{H}_{2} \mathrm{O}$ catalyst; B: Initial reaction mixture without grinding; C: Reaction mixture after $5 \mathrm{~min}$ of grinding; D: Reaction mixture after $10 \mathrm{~min}$ of grinding; E: Spectra of pure product 
The FT-IR studied the progress of reaction between $p$-chlorobenzaldehyde and 5, 5-dimethyl-1, 3cyclohexanedione (Fig. 1) under the optimized condition with ferric nitrate nonahydrate as catalyst at different time intervals from the beginning. The spectra B-D did not show any prominent signal for the catalyst $\mathrm{Fe}\left(\mathrm{NO}_{3}\right)_{3} .9 \mathrm{H}_{2} \mathrm{O}$ during the course of reaction, which may be due to the lower concentration of catalyst and its interaction with the reaction mixture.

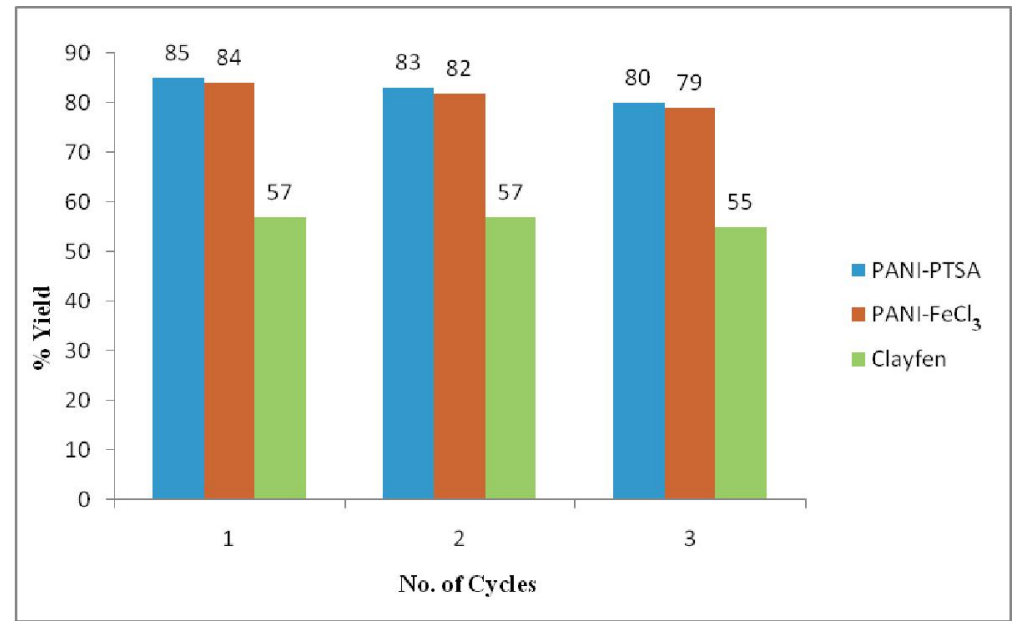

Fig. 2. Histogram of reusability of supported catalysts
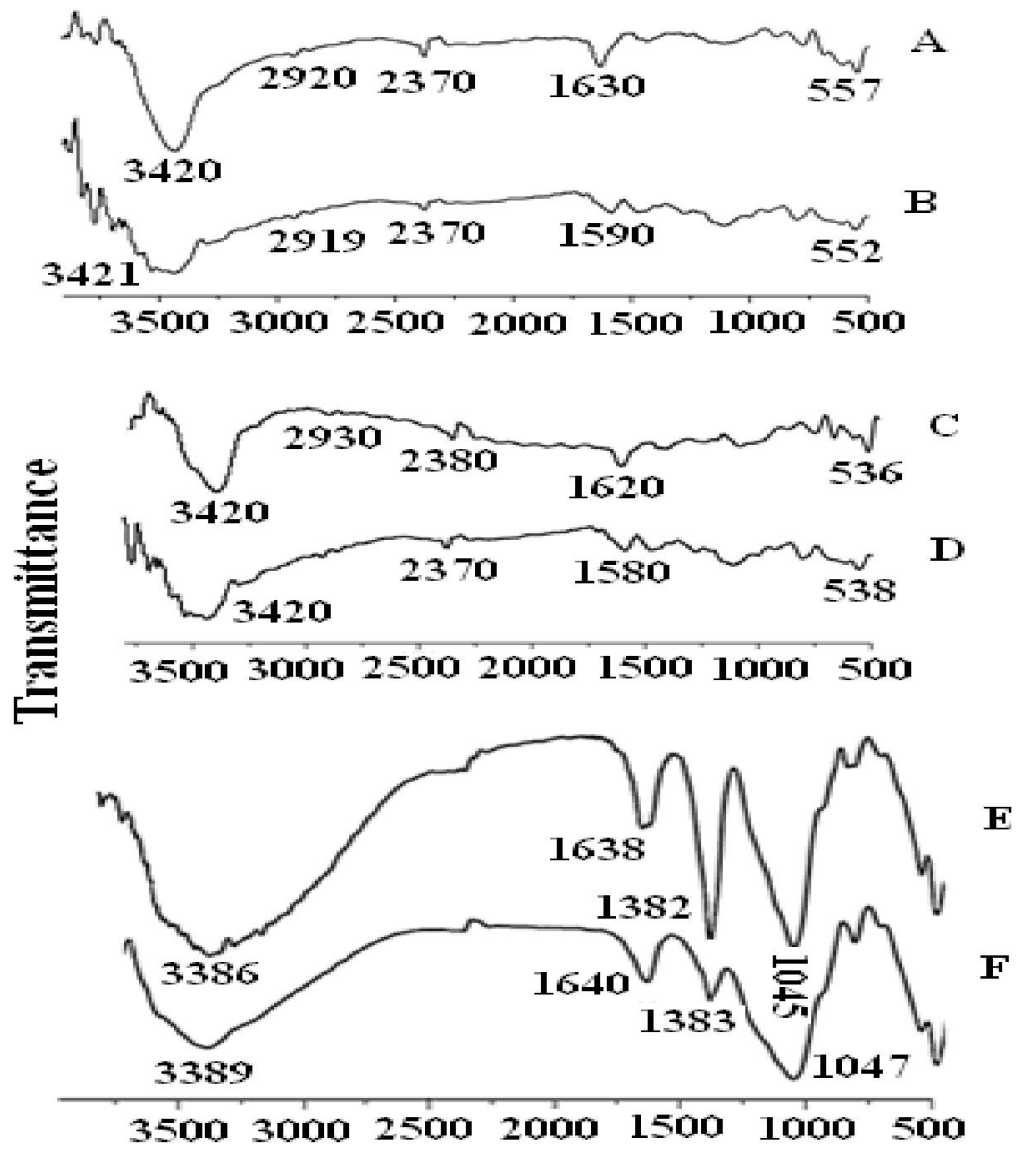

Fig. 3 FT-IR spectra of fresh and $3^{\text {rd }}$ recyclable catalyst. A : PANI-TsOH(fresh ); B: PANI-TsOH $\left(3^{\text {rd }}\right) ; \mathrm{C}: \mathrm{PANI}-\mathrm{FeCl}_{3}$;(fresh); D: PANI-FeCl $3\left(3^{\text {rd }}\right) ; \mathrm{E}$ : Clayfen (fresh $) ; \mathrm{F}$ : Clayfen $\left(3^{\text {rd }}\right)$ 
The reusability of the three supported catalysts (PANI-TsOH, PANI-FeCl, Clayfen) were investigated for three times (Fig. 2) with the reaction of $p$-chlorobenzaldehyde and dimedone in solvent-free method which were further supported by FT-IR spectra of reused catalyst up to $3^{\text {rd }}$ cycles (Fig. 3). The reusability of $\mathrm{Fe}\left(\mathrm{NO}_{3}\right)_{3} \cdot 9 \mathrm{H}_{2} \mathrm{O}$ catalyst in organic solvents was studied by dissolving the reaction mixtures in chloroform, dichloromethane, ethanol, ethyl acetate and diethyl ether after completion. The hygroscopic nature of the catalyst changed its state from solid to liquid in these solvents and made it very difficult to filter as solid residue from the solution for recycling.

\section{Conclusion}

This article investigates the activities of three reusable supported acid catalysts PANI-TsOH, PANI-FeCl $\mathrm{F}_{3}$ and Clayfen for the synthesis of xanthenedione derivatives in mild conditions with different aromatic aldehydes and dimedone under solvent-free grinding method. The ferric nitrate nonahydrate was found as an efficient and selective catalyst for this reaction in absence of support. The advantage of this protocol lies in the avoidance of organic solvent, high yield, energy efficiency, variation of substrates, and use of inexpensive reusable catalyst.

\section{Acknowledgements}

The authors are thankful to Sophisticated Analytical Instrumentation Centre and Department of Chemical Sciences, Tezpur University for analysis of various samples for this work.

\section{Experimental}

\subsection{Materials and Methods}

All chemicals are commercially available and were used without further purification. The products were identified by comparison of their FT-IR, ${ }^{1} \mathrm{H}$ NMR and ${ }^{13} \mathrm{C}$ NMR spectroscopic data with those of authentic compounds (prepared by known method) and literature reported data. ${ }^{13}, 14,18-20$ The polyaniline supported and Clayfen catalysts were prepared using already reported method. ${ }^{21,22}$

\subsection{Methods for the preparation of polyaniline supported acid catalysts:}

Three steps were involved for the synthesis of polyaniline supported $\mathrm{TsOH}$ and $\mathrm{FeCl}_{3}$ catalysts.

(i) Preparation of polyaniline salt.

A solution of $15 \mathrm{~mL}$ of sulphuric acid in $350 \mathrm{~mL}$ of water was prepared in a $500 \mathrm{~mL}$ round bottom flask with stirring. To the stirring solution, $5 \mathrm{~mL}$ of aniline was added at $5-10{ }^{\circ} \mathrm{C}$ and allowed to continue for stirring in presence of $130 \mathrm{~mL}$ aqueous solution of sodium persulfate $(12 \mathrm{~g})$ for $4 \mathrm{~h}$ at the same temperature. The polyaniline powder was precipitated, filtered and washed with $2 \mathrm{~L}$ distilled water followed by $200 \mathrm{~mL}$ acetone. The polyaniline salt powder was dried at $100^{\circ} \mathrm{C}$ till a constant weight $(3.5 \mathrm{~g})$.

(ii) Synthesis of polyaniline base.

In this step, $3.5 \mathrm{~g}$ of polyaniline salt powder was kept in a $500 \mathrm{~mL}$ round bottom flask and stirred in $300 \mathrm{~mL}$ aqueous sodium hydroxide solution $(1.0 \mathrm{M})$ for $8 \mathrm{~h}$ at ambient temperature. Polyaniline base was precipitated, filtered and washed with water and then with acetone. The base was dried at $100^{\circ} \mathrm{C}$ till a constant weight $(2.5 \mathrm{~g})$.

(iii) Redoped polyaniline salt.

Firstly, $50 \mathrm{~mL}$ of $1.0 \mathrm{M}$ two standard solution of $\mathrm{TsOH}$ and $\mathrm{FeCl}_{3}$ in acetone were prepared separately. To each of the above solutions, $0.5 \mathrm{~g}$ of polyaniline base was added and kept under 
constant stirring at ambient temperature for $4 \mathrm{~h}$. The supported catalyst was isolated through filtration, washed with acetone and dried at $100^{\circ} \mathrm{C}$ till a constant weight. Amount of acid group present in the polymeric chain was calculated based on the weight of redoped polyaniline salt obtained and the weight of polyaniline base used. Amount of dopant present in PANI-TsOH and PANI- $\mathrm{FeCl}_{3}$ were found to be $40.2 \%$ and $27.1 \%$ respectively.

\subsection{General procedure for the Synthesis of 1,8-dioxo-octahydroxanthene Derivatives 4 in Organic Solvent and solvent-free grinding method:}

A mixture of $0.5 \mathrm{mmol}$ of 4-chlorobenzaldehyde and $1 \mathrm{mmol}$ of 5, 5-dimethyl-1, 3cyclohexanedione in organic solvent $(3 \mathrm{~mL})$ is taken in a $25 \mathrm{~mL}$ round bottom flask containing 0.1 mmol of acid catalyst. For solvent-free method, the above mixture is grinded continuously with the help of mortar and pestle. The progress of the reaction in both conditions is monitored with the help of TLC technique. After completion, the reaction mixture is diluted with ethyl acetate and filtered to get the catalysts as residue. During the work-up step, the filtrate is diluted with aqueous sodium bicarbonate $\left(\mathrm{NaHCO}_{3}\right)$ solution and the organic part is extracted with ethyl acetate. The organic extract is dried over anhydrous sodium sulfate. The solvent ethyl acetate is distilled under reduced pressure to get the crude product. Recrystallization of crude product from ethanol yielded the pure product. The used catalyst is dried at $100^{\circ} \mathrm{C}$ and made ready for reuse.

\subsection{Spectral Data of Selected Compounds}

4.4.1. 9-Phenyl-3, 3, 6, 6-tetramethyl-1, 8-dioxo-octahydroxanthene 4a (Table- 2, Entry-1) ${ }^{23}$

${ }^{1} \mathrm{H}$ NMR $\left(400 \mathrm{MHz}, \mathrm{CDCl}_{3}\right) \delta \mathrm{ppm}: 0.95(\mathrm{~s}, 6 \mathrm{H}), 1.06(\mathrm{~s}, 6 \mathrm{H}), 2.15-2.26(\mathrm{~m}, 4 \mathrm{H}), 2.43(\mathrm{~s}, 4 \mathrm{H})$, $4.71(\mathrm{~s}, 1 \mathrm{H}), 7.06-7.24(\mathrm{~m}, 5 \mathrm{H}) ;{ }^{13} \mathrm{C} \mathrm{NMR}\left(100 \mathrm{MHz}, \mathrm{CDCl}_{3}\right) \delta \mathrm{ppm}$ :

196.4,162.1,144.1,128.4,128.07, 126.4,115.7,52.9,50.8,41.1,32.2,31.8,29.3,28.0,27.4; IR (KBr) :

$3439,2954,1663,1458,1362,1198,1146,1004,697 \mathrm{~cm}^{-1}$.

\subsubsection{9-(4-nitrophenyl)-3,3,6,6-tetramethyl-1,8-dioxo-octahydroxanthene 4c (Table-2, Entry-3) ${ }^{24}$}

${ }^{1} \mathrm{H}$ NMR $\left(\mathrm{CDCl}_{3}, 400 \mathrm{MHz}\right) \delta \mathrm{ppm}: 1.00(\mathrm{~s}, 6 \mathrm{H}), 1.13(\mathrm{~s}, 6 \mathrm{H}), 2.16-2.29(\mathrm{~m}, 4 \mathrm{H}), 2.51(\mathrm{~s}, 4 \mathrm{H})$, 4.84(s, $1 \mathrm{H}), 7.48(\mathrm{~d}, J=8.2 \mathrm{~Hz}, 2 \mathrm{H}), 8.10(\mathrm{~d}, J=8.72 \mathrm{H}) ;{ }^{13} \mathrm{C}$ NMR $\left(100 \mathrm{MHz}, \mathrm{CDCl}_{3}\right) \delta \mathrm{ppm}: 195.8$, 169.8, 148.7,147.9,145.8, 141.4, 129.4, 127.3, 123.8, 123.7, 110.7, 93.4, 50.6, 41.7, 32.7, 32.5, 29.6, 29.1, 27.8; IR (KBr): 3431, 2956, 1660, 1515, 1355, 1199, 1138, 1005, 869, $828 \mathrm{~cm}^{-1}$.

\section{References}

1. Bose A. K., Pednekar S., Ganguly S. N., Chakraborty G. and Manhas M. S. (2004) A simplified green chemistry approach to the Biginelli reaction using ' Grindstone Chemistry'. Tetra. Lett., 45, 8351-8353.

2. Delmas M. and Gaset A. (1980) Selective Synthesis of 4-aryl-1, 3-dioxanes from arylalkenes and paraformaldehyde using an ion exchange resin as catalyst. Synthesis, 11, 871-872.

3. Karthikeyan G. and Pandurangan A. (2009) Heteropolyacid $\left(\mathrm{H}_{3} \mathrm{PW}_{12} \mathrm{O}_{40}\right)$ Supported MCM41: An efficient solid acid catalyst for the green synthesis of xanthenedione derivatives. $J$ Mol. Cat. A: Chem., 311, 36-45.

4. Blaz E. and Pielichowski J. (2006) Polymer supported cobalt (ii) catalysts for the oxidation of alkenes. Molecules, 11,115-120.

5. Hummur R.K., Sunil Kumar B. and Kumar P.S. (2008) Silica sulfuric acid: a simple efficient, and reusable heterogeneous catalyst for the one-pot synthesis of aryl-14h-dibenzo [a,j] xanthenes under conventional heating and solvent-free conditions. Chem. Heterocyclic Comp., 44, 143-147.

6. Poupelin J. P., Saint-Rut G., Fussard-Blanpin O., Narcisse G., Uchida-Ernouf G., and Lakroin R. (1978) Synthesis and anti-inflmmatory properties of bis(2-hydroxy-1-naphthyl)methane, ii. polysubstituted and polycyclic derivatives. Eur. J Med. Chem., 13, 381-385. 
7. Ion R. M., Frack omiak D., Planner A., and Wiktoromicz K. (1998) The incorporation of various porphyrins into blood cells measured via flow cytometry, absorption and emission spectroscopy. Acta. Biochim. Poloni., 45,833-845.

8. Ahmad M., King T. A., Ko D. K., Cha B. H., and Lee, J. (2002) Performance and photostability of xanthene and pyrromethene laser dyes in sol-gel phases. $J$ Phy. D: Appl. Phy., 35, 1473-1476.

9. Hunter R. C., and Beveridge T. J. (2005) Application of a pH -sensitive Fluoroprobe (CSNARF-4) for $\mathrm{pH}$ Microenvironment Analysis in Pseudomonas Aeruginosa Biofilms. Appl. Environ. Microb., 71, 2501-2510.

10. Azebaze A. G. B., Meyer M., Valentin A., Nguemfo E. L., Formum Z. T., and Nkengfack A. E.(2006) Prenylated xanthone derivatives with antiplasmodial activity from Allanblackia Monticola Staner L.C. Chem. Pharm. Bull. 54, 111-113.

11. Demirkiran O. (2007) Xanthones in Hypericum : Synthesis and biological activities. Top. Heter. Chem., 9, 139-178.

12. Hatakeyam S., Ochi N., Numata H., and Takano S. (1988) A new route to substituted 3methoxycarbonyldihydropyrans; enantioselective synthesis of (-)-methyl elenolate. $J$ Chem. Soc. Chem. Commun. , 17, 1202-1204.

13. Venkatesan K., Pujari S. S., Lahoti R. J., and Srinivasan K. V. (2008) An efficient synthesis of 1,8-dioxo-octahydro-xanthene derivatives promoted by a room temperature ionic liquid at ambient conditions under ultrasound irradiation. Ultrason Sonochem, 15, 548-553.

14. Jin T. S., Zhang J. S., Wang A. Q., and Li T, S. (2005) Solid-state condensation reactions between aldehydes and 5,5-dimetyl-1,3-cyclohexanedione by grinding at room temperature. Syn. Commun., 35, 2339-2345.

15. Borah K. J. and Borah R. (2011) Investigation of prins reaction for the synthesis of 2, 4disubstituted tetrahydropyran derivatives and 1,3-dioxanes using polyaniline supported acid as reusable catalyst. J Chem. Sci., 123, 623-630.

16. Borah K. J. and Borah R. (2011) Poly(4-vinylpyridine)-supported sulfuric acid: an efficient solid acid catalyst for the synthesis of coumarin derivatives under solvent-free conditions. Monat. Für. Chem., 142, 1253-1257.

17. Phukan M., Kalita M. K., and Borah R. (2010) A new protocol for Biginelli (or like) reaction under solvent-free grinding method using $\mathrm{Fe}\left(\mathrm{NO}_{3}\right)_{3} .9 \mathrm{H}_{2} \mathrm{O}$ as catalyst. Green Chem. Lett. and Rev., 3, 329-334.

18. (a) Jin T., Zhang J., Xiao J., Wang A., and Li T. (2004) Clean Synthesis of 1,8-DioxoOctahydroxanthene Derivatives Catalyzed by $p$-Dodecylbenzenesulfonic Acid in Aqueous Media.' Synlett, 5, 866; (b) Song G., Wang B., Luo H., and Yang, L. (2007) $\mathrm{Fe}^{3+}$ Montmorillonite as a cost effective and recyclable solid acidic catalyst for the synthesis of xanthenediones. Cat. Commun., 8, 673-676.

19. (a) Fan X., Hu X., Zhang X., and Wang J. (2005) $\mathrm{InCl}_{3} .4 \mathrm{H}_{2} \mathrm{O}$-promoted green preparation of xanthenedione derivatives in ionic liquids. Can. J. Chem., 83, 16-20. (b) Jung D. H., Lee Y. R., Kim S.H., and Lyoo W.S. (2009) New and general methods for the synthesis of arylmethylene Bis(3-hydroxy-2-cyclohexene-1-ones) and xanthenediones by EDDA and In(OTf) $)_{3}$-catalyzed One-pot domino Knoevenagel/Michael or Knoevenagel/Michael/cyclodehydration reactions. Bull. Korean.Chem.Soc., 30, 1989-1995.

20. Das B., Thirupathi P., Reddy K. R., Ravikanth B., and Nagarapu L. (2007) An efficient synthesis of 1,8-dioxo-octahydroxanthene using heterogeneous catalysts. Cata. Commun., 8, 535-538.

21. Gangadasu B., Palaniappan S., Amarnath C. A., and Rao V. J. (2006) Polyaniline salts and complexes : efficient and reusable catalyst for the one-pot synthesis of 5-(methoxycarbonyl)6-methyl-4-phenyl-3,4-dihydropyrimidin-2(1H)-one. J Appl. Poly. Sci., 102, 1741-1745.

22. Badathala V. ( 2004) Clay Catalysts in Organic Synthesis. Synlett, 388-389. 
23. Hu X-Y., Fan X. S., Zhang X-Y., and Wang J-J. (2005) A Green and efficient synthesis of xanthenedione derivatives promoted by $\mathrm{InCl}_{3} \cdot 4 \mathrm{H}_{2} \mathrm{O}$ in ionic liquid. Chin. Chem. Lett., 16, 293- 295.

24. Jin T. S., Zhang J. S., Wang A.Q., and Zhang F. S. (2005) Synthesis of 3,3,6,6-tetramethyl-9aryl-1,8-dioxo-1,2,3,4,5,6,7,8-octahydroxanthene in aqueous media. Chin. J Org. Chem., 25, $335-338$. 